\title{
Simulation over Load Protection 1-Phase on-Load Household with a Microcontroller
}

\author{
Deitje Sofie Pongoh \\ Department of Electrical \\ Engineering, \\ Manado State Polytechnic
}

\author{
I Gede Para Atmaja \\ Department of Computer \\ Engineering, \\ Manado State Polytechnic
}

\author{
Tony Kurtis Timpua \\ Department of Environmental \\ Health, \\ Manado Health Polytechnic
}

\begin{abstract}
Rapid development of technology today has penetrated into various fields. Technology it is present and developing continuously along with the increasing human needs, one of the technologies developed, namely the microcontroller.

A microcontroller is a device control on the be used as a main control on a system that is both simple and complex. In the Final project with the title "System Overcurrent Protection Single Phase Using a Microcontroller Atmega 8535". As the main control on the system are made. This system acts as a protection on the electrical system where if the load current has exceeded the limit then the system will decide contact the supply automatically.

On the protection system are made, the detection of current using a current transformer to convert the magnitude of the current into a voltage and the magnitude of the voltage will be measured by the microcontroller as a reference for control contacts supply power to the load, the magnitude of the load that is supplied is set using the input set point to the microcontroller if the current detected exceeds the set point of the supply is decided automatically.
\end{abstract}

\section{Keywords}

Current transformer, Over Load, Protection System

\section{INTRODUCTION}

A control system automatically in the field of science and technology these days is growing rapidly. With the advances in the field of science and technology to produce new innovations that are evolving towards the better. It can be seen the range of application ranging from household appliances to sophisticated equipment. Development and tool overload protection is still limited to the expenses of the household so that many household appliances suffered damage due to a short circuit current and unstable voltage on the load. In the current era of globalization, we are not apart from the development and progress of technology. The current ease and efficiency of personnel as well as the time be the primary consideration of the human in performing the activity. From time to time we are faced with the rapid development of technology so as to make human work easier.

\section{METHODOLOGY}

\subsection{Stageinitial Diagnosis}

To know the process of making a Simulation Over Load Protection 1-Phase On-load Household With microcontroller ATMega8535 carried out research study on the control system.

\subsubsection{Materials and Equipment Research}

The materials required in the manufacture of tools is the materials that we have chosen before it the materials to make the mechanical, and the series. The materials used are: Microcontroller Atmega 8535, the Module Downloader Nue 125, Stop Contact ,C LM324, LCD Display, Kepad 3x4, Relay, Optocoupler, transistor, Led indicator, Resistor $10 \mathrm{~K} \Omega$, Resistor $1 \mathrm{~K} \Omega$, Resistor $220 \Omega$, Elko $2200 \mathrm{uF} / 16 \mathrm{~V}$, Capacitor $33 \mathrm{pF}$, a Crystal Of $11.0592 \mathrm{Mhz}$, PCB Matrix, data Cable, Software Compiler and Downloader, Mica, Aluminum.

\subsubsection{Methods and Implementation Research}

In this study using the method of design begins with a prototype design over load protection and design Protection system of over load 1-phase on-load household with a microcontroller. Then perform system testing and evaluation of hardware and software.traffic congestion and traffic accident information.

\subsection{The planning stage}

On the system design before designing the hardware and software, we need to create a block diagram of a system that serves as a reference of how the system was built and working. So that we can determine what kind of hardware and software that we will create. Fig. 1 shown the block diagram of the Overcurrent Protection 1-Phase By Using Microcontroller Atmega8535.

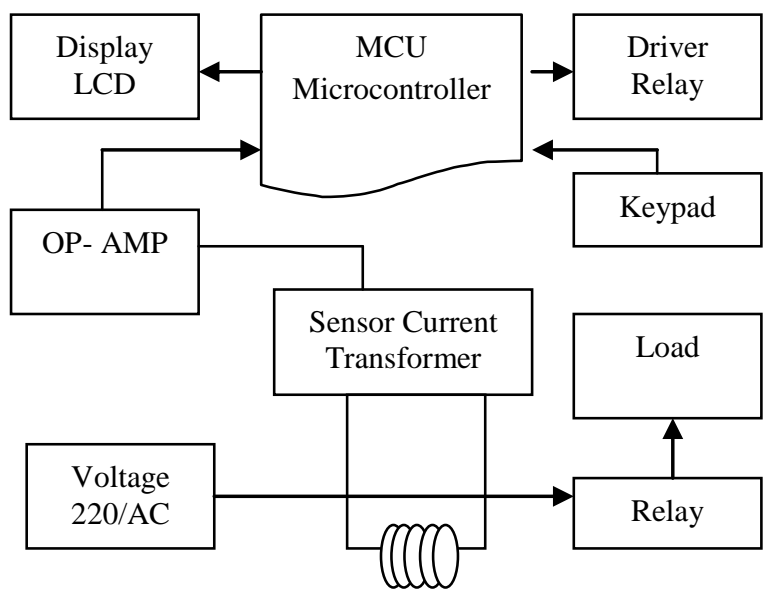

Fig.1. Block Diagram of the system

\subsection{Hardware Design}

In the manufacture of tool Protection System Overcurrent 1 Phase by using Microcontroller Atmega8535, first need to be designed hardware. In fig. 2 is shown a design layout of a layout of the electronic circuit, the stop contacts the load, a current sensor, relay, transformer, keypad and LCD display. 


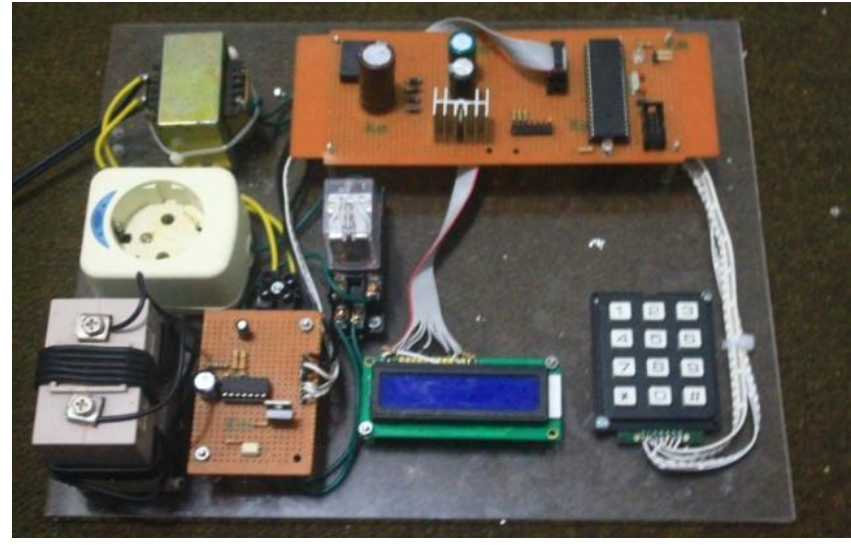

Fig.2. Draft layout

In its design we refer to a circuit system, such as the circuit power supply, the Amplifier Op-Amp, Relay Driver, and the Minimum System Microcontroller ATmega8535.Here is a picture of a circuit used in the tool protection system overcurrent 1 phase. In the manufacture of tool Protection System Overcurrent 1 Phase which is controlled by a Microcontroller Atmega8535, need a program, i.e. a set of instructions logic that will be implanted on the chip of a microcontroller. Where the design software specialized program, created after we designed the hardware. In the manufacture of tool Protection System Overcurrent 1 Phase which is controlled by a Microcontroller Atmega8535, need a program, i.e. a set of instructions logic that will be implanted on the chip of a microcontroller. Where the design software specialized program, created after we designed the hardware.

\section{RESULTS AND DISCUSSION}

After the process of design and assembly tool, it should do the testing on the tool made. Where the testing tool is divided into two parts, namely testing devices hardware and software testing. After we did the testing on some of the tools manually or separately.And after install the application compile and download to the microcontroller. We will also perform testing of the device, which in the previous stage should not be done manual testing. Therefore, in testing the device like a keypad and LCD, we just do the testing as a whole.To be able to see the results of a series we make. And to see the work of the program on the microcontroller that we have download.

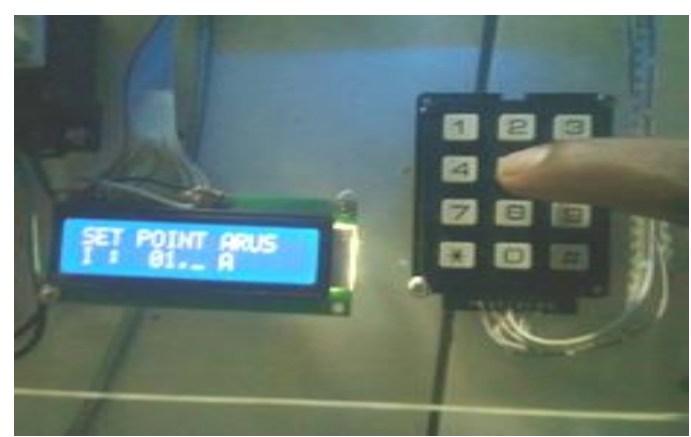

Fig. 3 Initial View of the system

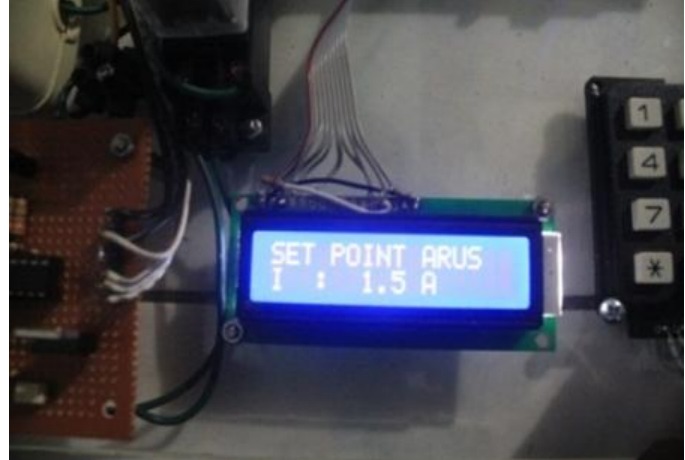

Fig. 4 Input Set Point Value 01,5 Amp / 1.5 Amp

From this test it can be concluded, that the LCD, Keypad, and other circuits have been tested manually works as it should. Below is the data obtained from load testing of incandescent Lamps with different power. Where the set point tool set 0.80 Amp

Table 1. The Results of the Experiment I

Incandescent lamps of 100 watts, I set $=0.80 \mathrm{~A}$

\begin{tabular}{|c|c|c|}
\hline \multicolumn{2}{|c|}{ Electric current (A) } & \multirow{2}{*}{ Description } \\
\cline { 1 - 2 } Measuring & Relay (A) & \\
\hline 0,06 & 0,065 & No. Trip \\
\hline 0,1 & 0,099 & No. Trip \\
\hline 0,15 & 0,14 & No. Trip \\
\hline 0,20 & 0,19 & No. Trip \\
\hline 0,25 & 0,23 & No. Trip \\
\hline 0,30 & 0,29 & No. Trip \\
\hline
\end{tabular}

Table 2. The results of the Experiment II

Incandescent lamps of 100 watts, I set $=0.35 \mathrm{~A}$

\begin{tabular}{|c|c|c|}
\hline \multicolumn{2}{|c|}{ Electric current (A) } & \multirow{2}{*}{ Description } \\
\cline { 1 - 2 } $\begin{array}{c}\text { Measuring } \\
\text { Instruments }\end{array}$ & $\begin{array}{c}\text { Measuring } \\
\text { Instruments }\end{array}$ & \\
\hline 0,05 & 0,06 & No. Trip \\
\hline 0,10 & 0,09 & No. Trip \\
\hline 0,15 & 0,13 & No. Trip \\
\hline 0,20 & 0,23 & No. Trip \\
\hline 0,25 & 0,25 & No. Trip \\
\hline 0,30 & 0,32 & No. Trip \\
\hline 0,35 & 0,36 & TRIP \\
\hline
\end{tabular}


The presentation of error values obtained from the test results is:

Experiment 1:

$$
\begin{aligned}
& E(\text { error })=\frac{\mathbf{0 , 0 6 5 - 0 , 0 6}}{\mathbf{0 , 0 6 5}} \times 100 \%=7,9 \% \\
& E(\text { error })=\frac{\mathbf{0 , 0 6 5 - 0 , 0 6}}{\mathbf{0 , 0 6 5}} \times 100 \%=7,9 \% \\
& E(\text { error })=\frac{\mathbf{0 , 0 9 9 - 0 , 1}}{\mathbf{0 , 0 9 9}} \times 100 \%=1,01 \% \\
& E(\text { error })=\frac{\mathbf{0 , 1 4 - 0 , 1 5}}{\mathbf{0 , 1 4}} \times 100 \%=7,14 \% \\
& E(\text { error })=\frac{\mathbf{0 , 1 9 - 0 , 2 0}}{\mathbf{0 , 1 9}} \times 100 \%=5,26 \% \\
& E(\text { error })=\frac{\mathbf{0 , 2 3 - 0 , 2 5}}{\mathbf{0 , 2 3}} \times 100 \%=8,69 \% \\
& E(\text { error })=\frac{\mathbf{0 , 2 9}-\mathbf{0 , 3 0}}{\mathbf{0 , 2 9}} \times 100 \%=3,45 \% \\
& E(\text { error })=\frac{\mathbf{0 , 3 3 - 0 , 3 5}}{\mathbf{0 , 3 3}} \times 100 \%=6,06 \%
\end{aligned}
$$

Experiment 2:

$$
\begin{aligned}
& E(\text { error })=\frac{\mathbf{0 , 0 6}-\mathbf{0 , 0 5}}{\mathbf{0 , 0 6}} \times 100 \%=16,6 \% \\
& E(\text { error })=\frac{\mathbf{0 , 0 9}-\mathbf{0 , 1}}{\mathbf{0 , 0 9}} \times 100 \%=11,1 \% \\
& E(\text { error })=\frac{\mathbf{0 , 1 3}-\mathbf{0 , 1 5}}{\mathbf{0 , 1 3}} \times 100 \%=15,38 \% \\
& E(\text { error })=\frac{\mathbf{0 , 2 3 - 0 , 2 0}}{\mathbf{0 , 2 3}} \times 100 \%=13,04 \% \\
& E(\text { error })=\frac{\mathbf{0 , 2 5}-\mathbf{0 , 2 5}}{\mathbf{0 , 2 5}} \times 100 \%=0 \% \\
& E(\text { error })=\frac{\mathbf{0 , 3 2 - 0 , 3 0}}{\mathbf{0 , 3 2}} \times 100 \%=7,25 \% \\
& E(\text { error })=\frac{\mathbf{0 , 3 6}-\mathbf{0 , 3 5}}{\mathbf{0 , 3 6}} \times 100 \%=2,78 \%
\end{aligned}
$$

\section{CONCLUSIONS}

The conclusions obtained from the discussion of previous chapters are as follows:

From the test data and analysis that the authors get, measurement of current detected tool This protection system still has the difference with the measurement directly using the meter ampere meter, the current difference ranges from 0 to $15 \%$, Voltage converted to current from output travo current can not directly input to microcontroller, because for large currents output voltage from travo also bigger, if inputted directly to ADC Microcontroller can damage microcontroller therefore at voltage down and inputed first to Op-Amp for scale gain.

\section{ACKNOWLEDGMENTS}

Thanks to the Ministry of Research and Technology of Technology and Higher Education, which has funded this research with competitive grants program in 2017 , so as to do research and work well.

\section{REFERENCES}

[1] Afrianto Deni, (2011), "Kamus Komponen Elektrikal", Kawan Pustaka, Jakarta.

[2] Blocher Richard,(2004), "Dasar Elektronika”, Andi, Yogyakarta

[3] Braunl, Embedded Robotics, Springer, 2005 Barmawi, Andi, Prinsip-Prinsip Elektronika Edisi Ketiga Jilid 2 (Terjemahan). Jakarta : Erlangga 1991

[4] Budiharto, Widodo, Kontrol Cerdas, Elexmedia Komputindo,2005

[5] Drs. Daryanto,(2002), "Pengetahuan Teknik Listrik", Bumi Aksara, Jakarta Efvy

[6] Meystel, A., 2000, Autonomous Mobile Robots Vehicles with CognitiveControl, World Scientific, Singapore

[7] Nourbakhsh, illah R., 2000, Property Mapping: a simple technique for mobilerobot programming, proceedings of AAAI 2000

[8] Pitowarno, Endra, Robotika Disain, Kontrol dan Kecerdasan Buatan, Andi Offset, 2006

[9] Williams,Karl, C Programming, McGraw Hill 2004 Sumanto,Elektronik Industri (Terjemahan). Jakarta Erlangga 2001.

[10] Zamidra Zam, Mudah Menguasai Elektronika, Indah, 2002. 